\title{
Molecular Cloning of Immunoglobulin Gamma Gene from a Patient with Myeloma
}

\author{
by \\ Michitoshi Nakamura and Shogo Masumi \\ Department of Orthopedic Surgery \\ Medical Collage of Oita, Oita, Japan
}

Messemger RNA was purified from the tumor at the distal end of right clavicula of the myeloma patient.

The concentration of gamma chain in the total polyA ${ }^{+} \mathrm{RNA}$ was estimated as about $1 \%$ by hybridization. Under the restriction of $\mathrm{P} 2$ level, cDNA library was constructed using Amersham's kits. The efficiency of the cloning reached to $4.5 \times 10^{7}$ pfu per eg cDNA. Seven positive plaques from 500 plaques were picked up and purified. Each clone had an about $300 \mathrm{bp}$ insert which was hybridized to the probe.

\section{Introduction}

Recent rapid progress of the knowlege using the molecular biologic techniques has influenced even the clinical medicine. Following the extesive adoption of these techniques, many supplyers have developed and offered the materials which were used in molocular biology especially purified enzymes. To use these enzymes or well constructed systemic kit have made the research easier.

On the other hand, immunoglobulin family gene is one of the well charactered gene family. We could get the immunogulobulin gamma $=1$ gene as a probe. This probe was originally developed by Prof. Honjo and co-workers ${ }^{4)}$ and was delivered to us by the courtesty of the Japanese Cancer Reseach Resource Bank-Gene (JCRB).

To check our newly established labolatory system, we have tried the molecular cloning of the immunogulobulin gamma gene from the tumor of the patient with myeloma. Successful result encourage us to continue the study of the clinical problems from the view of molecular biology.

\section{Patient, material and method}

Patient: A 60-years old woman. She had a sudden pain at her right shoulder at the moment she held a grandson in her arms. Rentogenography revealed the osteolytic lesion at the distal end of the clavicle. Diagnosis was confirmed by the results of serum chemistry as a IgG $k$ type myeloma. Because she suffered from the pain and limitation of the shoulder movement caused by the pathologic fracture, we dicided to widely resect the tumor and reconstruct the right shoulder.

Material and Method: After surgery, tumor was immediately freezed at $-80^{\circ} \mathrm{C}$. Basic techniques were described in the textbook ${ }^{2,3)}$. After one night melting at $4{ }^{\circ} \mathrm{C}$, tumor tissue was cutted into $5 \mathrm{~mm}$ cubes. Guanidium solution ( $5 \mathrm{ml}$ ) was added per $1 \mathrm{~g}$ tissue, homogenate was prepared by Silverson's Polytron. Then, hot phenol extaction was done as described by Feramisco et al $^{11}$. 




Figure 1 Dot Blot Hybridization

$\mathrm{B}$ and $\mathrm{C}$ : $\mathrm{PolyA}^{+}$RNA from myeloma,50ng and $5 \mathrm{ng}$ respectively. $\mathrm{A}$ and $\mathrm{D}$ to $\mathrm{J}$ : Other experimemts to determine the concentration of gamma chain. 10 0.5: marker DNA (probe itself) unit pg.

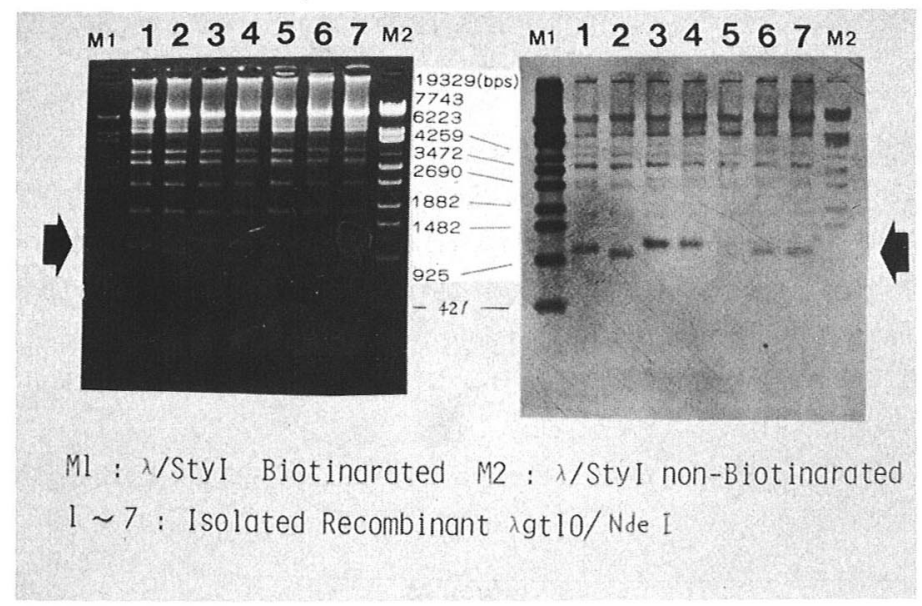

Figure 2 Detection of the inserted DNA

Right: Electrophoresis of purified phage digested by Ndel. M 1 marker was biotinarated by the Potobiotin ${ }^{\circledR}$ (see text).

Left: DNA-DNA hybridization of the right electrophoresis. Arrows indicate the various length fragments due to the inserted DNA.

After ethanol precipitation, precipitate was dissolved in the Guanidium solution. This solution was layered onto a sesium chloride cushion, and centrifuged at $35,000 \mathrm{rpm}$ for $12 \mathrm{hours}$. Precipitated total RNA was applied on to the oligo (dT) -cellulose (New England Biolabs, MA, USA) column. Purified mRNA was dotted on the nylon membrane (Hybond- ${ }^{\circledR}$, Amersham) to estimate the concentration of the immunogulobulin gamma-1. Nylon membrane was treated by the hybridization protocol of supplyer. On the other hand, probe DNA was prepaered from the plasmid which was originally developed by prof. Honjo. This named HIg $\gamma 1-10$ (JCRBgene deposit number HG 016) has a human genomic $\mathrm{C} \gamma 1$ gene at Hind III site of pBR322.

$$
-313-
$$




\begin{tabular}{|c|c|c|c|c|c|c|c|c|c|}
\hline & DNA & insert & $\begin{array}{l}\text { L87 } \\
\text { titer }\end{array}$ & $\begin{array}{l}\text { NM514 } \\
\text { titer }\end{array}$ & $\begin{array}{c}\text { L87 }: \text { NM514 } \\
\text { ratio }\end{array}$ & background & $\begin{array}{c}\text { total } \\
\text { recombinant }\end{array}$ & $\begin{array}{c}\text { recombinant } \\
\%\end{array}$ & $\begin{array}{l}\text { recombinant } \\
\text { per } \mu \mathrm{g} \text { cDNA }\end{array}$ \\
\hline tube 1 & $\lambda \mathrm{gt} 10$ & - & $1.5 \times 10^{7}$ & $3.3 \times 10^{4}$ & 455 & & & & \\
\hline \multirow[t]{2}{*}{ tube 2} & $\lambda$ gt 10 & - & & & & & & & \\
\hline & EcoRI arm & - & $2.5 \times 10^{7}$ & $1.1 \times 10^{5}$ & 227 & & & & \\
\hline \multirow[t]{2}{*}{ Control } & $\lambda \operatorname{gt} 10$ & & & & & & & & \\
\hline & EcoRI arm & $30 \mathrm{ng}$ & $5.7 \times 10^{7}$ & $1.0 \times 10^{7}$ & 5.7 & $2.5 \times 10^{5}$ & $9.8 \times 10^{6}$ & $98 \%$ & $3.3 \times 10^{8}$ \\
\hline \multirow[t]{2}{*}{ Myeloma } & $\lambda \mathrm{gt} 10$ & & & & & & & & \\
\hline & EcoRI arm & $60 \mathrm{ng}$ & $4.2 \times 10^{7}$ & $2.9 \times 10^{6}$ & 14 & $1.9 \times 10^{5}$ & $2.7 \times 10^{6}$ & $93 \%$ & $4.5 \times 10^{7}$ \\
\hline
\end{tabular}

Table 1 Summary of cDNA library Construction

$\lambda$ gt10 phage has only one EcoRI site in the gene of repressor (cI). So intact $\lambda$ gt10 is induced to lysogenic pathway in E. coli L87 strain and is forced to lysogenic pathway in E. coli NM514 strain $\left(\mathrm{hfl}^{+}\right)$. Once a DNA is inserted at the EcoRI site, this recombinant $\lambda$ gt10 is free from lysogenization and then expresses the clear plaque on the host plate especially NM514. Arm selective ratio (L87: NM514 ratio) in tube 2 can be used to caliculate the background, because this ratio is decided by the lots of the host and arm used in this experiment series.

Cutted insert fragmemt was recoverd from the agarose gel and labelled by biotin using nick translation methods. Detection was done by the BluGENE ${ }^{\circledR}$ (BRL, USA).

$\mathrm{PolyA}^{+}$RNA was converted to the double stranded DNA by the cDNA synthesis system supplyed by Amersham. After the purification by the NACS PREPAC ${ }^{\circledR}$ (BRL), synthesised blant double stranded DNA (60ng) was cloned into the $\lambda$ gt10 using the system of Amersham's kit.

Marker DNA ( $\lambda /$ StyI) was purchased from NIPPON GENE (Japan) and labelled by the protocol of Photobiotin ${ }^{\circledR}$ (BRESA, Australia).

Other chemicals and biological active reagents were mainly obtained from SIGMA, TOYOBO and TAKARA.

\section{Results}

Two microlitter solution of mRNA and same volume of marker (probe itself) were blotted on the nylon membrane. Spot $\mathrm{C}$ in figure 1 shows more strong color than that of marker 10 which means 10pg. Other experimemts (deta not shown) also reveal that purified mRNA from the myeloma has $1 / 100$ density of marker. This means that about $1 \%$ of mRNA is the immunoglobulin gamma gene.

Five micrograms of mRNA were converted to the blant double strand DNA by the Amersham's kit. Consequentially this cDNA was cloned into $\lambda$ gt10. Results of this construction of cDNA library were summarized in table 1 . Based on the data of the mRNA hybridization, only 500 plaques were screened. This hybridization condition was described elswhere ${ }^{4}$. After hybridization, detection was done using Biotin/avidin system. Eight positive plaques were isolated from cDNA library, and out of all, seven clones were identified as a clone of the immunoglobulin gamma gene by the hybridization.

Figure 2 shows one of the electrophoreses and its hybridization. Several different length 
fragmemts were hybridized to the probe. Exact lengths of inserted DNA were dicided by EcoRI digestion (data not shown). The lengths of inserted DNA were varied from 100 to $500 \mathrm{bp}$.

\section{Discussion}

In recent decade, many companies began to supply the materials which were used in molecular biology. On the other hand, each technique of the fields has been refined. These developments of matelial and technique made the molecular biologic approach to the clinical problems easier. We had established the P 2 level laboratory for recombinant gene and started the some projects. To check our system, we tried to construct the cDNA library and to select the clone from clinical material. And we adopted the biotin/avidin system instead of the ${ }^{32} \mathrm{P}$ for detection, because it has very short half life time for our clinicians.

After all, these detection systems and Amersham's kits worked well. Only about the problem of the inserted DNA length, we have an optimistic view about the myeloma.

Finally, we point out that "how to purify the intact RNA from pathologic tissue?" is the key for these molecular biologic studies.

\section{References}

1) Feramisco, J. R., Smart, J. H., Burridge, K., et al.: Co-existance of Vinculin-like Protein of Higher Molecular Weight in Smooth Muscle. J. Biol. Chem. 257 : 11024-11031, 1982

2) Maniatis, T., Fritsch, E. F. and Sambrook, J: Molecular Cloning, A Labolatory Mansal: Cold Spring Harbor Laboratory, New York,1982

3) Takagi Yasuyuki ed: Manual of Gene Recombination: Koudanuya, Tokyo, 1982 (Japanese)

4) Takahashi Naoki, Ueda Shintaro, Obata Masahiro, et al: Structure of Human Immunoglobin Gamma Genes: Implications for Evolution of a Gene Family. Cell 29:681-679, 1982

\section{免疫グロブリン $\gamma$ 鎖のクローニング \\ 大分医科大学 整形外科 \\ 中 村 道 利・真 角 昭 吾}

右鎖骨遠位端から軟部に侵入したミエローマ腫瘤を 切除標本として,これから mRNA を精製した. 免疫グ ロブリン $\gamma$ 鎖は約 $1 \%$ の濃度で含まれていた. Amersham 社の cDNA 合成およびクローニングキットを用 いて cDNA を合成し， $\lambda \mathrm{gt} 10$ にクローニングした．計

\section{質 問長崎大学 平野 徹}

先生の研究は, 具体的にどのような整形外科疾患の 研究に応用できますか.
算上 270 万個のクローンを得た．約500個のプラークを 調べ， 7 個の陽性クローンを分離した。

実験は大分医科大学 P 2 レベル組み換え実験室で行 つた. 